\title{
Impact of White Collar Crime and Essence of Special Enactment: Bangladesh Perspective
}

\author{
Aroj Ali* \\ Lecturer and Head, Dept. of Law, North Western University, Khulna, 236, M. A. Bari Road, Sonadanga, \\ Khulna-9100, Bangladesh.
}

*Corresponding Author: Aroj Ali, Lecturer and Head, Dept. of Law, North Western University, Khulna, 236, M. A. Bari Road, Sonadanga, Khulna-9100, Bangladesh

\begin{abstract}
White Collar Crime is one of the major evils in the modern world. This study looks into this dreadful issue of White Collar Crime as it emerged awfully in some of the third world countries including Bangladesh. It is not an isolated phenomenon in itself but closely linked with various socio-economic factors of some post-colonial nations. This study also focuses on the present impact of this heinous crime on the society as well as on the administration of justice in Bangladesh. A number of bygone years have witnessed the rise of this evil doings in every aspects of the society and now it has become a crying need to enact special laws to encounter with this crime as the offenders of this crime are exceptional in nature. This study also shows the possible outcome of various efforts which should be taken by Government so as to protect the society from the curse of this crime.
\end{abstract}

Keywords: White Collar Crime, Blue Collar Crime, Enactment, Bangladesh

\section{INTRODUCTION}

The concept of White Collar Crime (WCC) has always been a phenomenon after the colonization and industrialization in the eighteenth century. But before Sutherland, no criminologists used this term or took the concept of white collar crime in the context of criminology. In Bangladesh only a several universities try to include this idea in their curriculum. A White Collar criminal belongs to upper socio-economic class who violates the rules for economic gain while performing his professional duties. White Collar Crime is also done by the professionals by using the influence of his peer groups. The introduction of White Collar Crime was a relatively new issue to criminology at that time. Bangladesh feels the essence of statutory provision for the prevention of White Collar Crimes since many years ago.

\section{BACKGRound OF White Collar CRime (WCC)}

The Genesis of White Collar Crime is not that ancient. The term White Collar Crime dates back to 1939. As said earlier Professor Edwin Hardin Sutherland was the first to coin the term, and hypothesize White Collar criminals attributed different characteristics and motives than typical street criminals. Mr. Sutherland originally presented his theory in an address to the American Sociological Society in attempt to study two fields, crime and high society, which had no previous empirical correlation. He defined his idea as "crime committed by a person of respectability and high social status in the course of his occupation". Many denote the invention of Sutherland's idiom to the explosion of U.S business in the years following the Great Depression. Finally E.H. Sutherland through his pioneering work emphasized that these 'upper world' crimes which are committed by the persons of upper socio-economic groups in course of their occupation violating the trust, should be termed "White Collar Crime" so as to be distinguished from traditional crime which he called, "Blue Collar Crime". Thus he observed that if a broker shoots his wife's lover, that is not a White Collar Crime, but if he violates the law and is convicted in connection with his business, he is a White Collar Criminal. [1]

The term "White Collar Crime" has been in frequent use in the literature of American Criminology since December 1939 to indicate the practice of chicanery and lotion of highly placed persons. In December, 1939 Edwin H. Sutherland used the term "White Collar Crime" in his presidential address 
before the American Sociological Society. There was no official or legal definition, for that reason the term was a bit ambiguous and controversial. Sutherland used "White Collar Crime" as the title for his remarks. He discussed the issues relating to "White Collar Crime" and later on elaborated many of its ramifications. Sutherland starred systematic research into the criminal practice of the elites after the appearance of the first edition of his "Criminology" in 1924. In second (in 1934) and third edition (in 1939), he changed the title of the book (Principles of Criminology) and subsumed scattered comments on White Collar Crime. But his 1939 presidential address was his first systematic formulation of the term, which was subjected to criticism of different quarters. He responded to those criticisms in his article "Is 'White Collar Crime,' crime?" published in 1945. He published a hook length study "White Collar Crime" in 1949, where he accumulated the data which he collected during many years research. He systematically presented his arguments and discussed the implications of the theory.[2]

\section{Concept of White Collar Crime and Definition}

Every day we observe many sorts of crimes happening around us. These crimes are theft, robbery, murder, snatching, rape, fraud, kidnapping, sedition, invasion, defamation etc. These kinds of crimes are regarded as heinous crimes in our society. But apart from these kinds of usual crimes, there are some specific crimes which are more maleficent for the society or state which impacts are not less than the mentioned above. These kinds of crimes apparently don't seem us terrible or immoral types.

White Collar Crime is a number of miscellaneous nonviolent crimes lumped together as White Collar Crimes. There is no fixed definition of white collar crime, although it usually includes Bribery, embezzlement, fraud, forgery, and violations of trust committed by corporations or individuals engaged in commerce. The concept of "white collar crime" found its place in criminology for the first time in 1941 when Sutherland published his research paper on white collar criminality in the American Sociological Review. He defined white collar crime as a "crime committed by persons of respectability and high social status in course of their occupation". A white-collar criminal belongs to upper socio-economic class who violates the criminal law while conducting his professional qualities.

- According to Richard T. Scharfer, "White Collar Crime is the crimes committed by affluent, respectable individuals in the course of business activities".

- According to Gossami, "Some authority suggest that white collar crimes are committed not for need but for greed."

- Sir Walter Recklers said that white collar crime represents offences of business man who are in a position to determine the policies and activities of business of politics."

\section{TyPes of White Collar CRime}

There are many types of White Collar Crime.

- Based on the definition of Clinard and Quinney who divided White Collar Crime into occupational crime and corporate crime, White Collar Crime can be categorized as follows:

$>$ Criminal misappropriation of property

$>$ Criminal breach of trust

$>$ Cheating /fraud

$>$ Forgery/credit/ATM card fraud

$>$ Counterfeiting currency or product

$>$ Defamation

$>$ Product piracy

$>$ Cyber crime

$>$ Offenses of communications and multimedia industries

$>$ Offences of printing and publication

$>$ Banking / financial fraud 
Loan sharking

$>$ Securities fraud/ Listing offences/ Insider trading

$>$ Money laundering

$>$ Insurance fraud

$>$ Maritime fraud

$>$ Offences of company

$>$ Tax evasion

$>$ Customs and smuggling offences

$>$ Immigration and human trafficking offences

$>$ Bribery and corruption

$>$ Exchange control violations

$>$ Welfare Fraud

$>$ Telemarketing Fraud

$>$ Larceny/Theft

$>$ Kickback

$>$ Insider Trading

$>$ Health Care Fraud

$>$ Extortion

$>$ Environmental Schemes

$>$ Embezzlement

$>$ Blackmail

$>$ Cellular Phone Fraud

$>$ Computer fraud

- According to Herbert Edel Hertz White Collar Crime is of 4 types: [3]

$>$ Offence individually related: Tax evasion, Insurance fraud, Non-payment of debt

> Professional Offence: Taking bribery, Corruption, Harassing Peoples

$>$ Offence relating to business: Misrepresentation in advertizing

$>$ Taking offence as businessman: Fraud in health sector, Forgery in land cases, Religious fraud

- According to August Bequal White Collar Crime is of Nine types:

Security related crimes

$>$ Bankruptcy crimes

> Misrepresentation in public cost/allotment by officers

$>$ Fraudulent presentation in advertisement

$>$ Computer or cyber crimes

$>$ Insurance fraud

$>$ Tax fraud

$>$ Bribery

$>$ Insider related fraud. 
- According to Prof. Sutherland:[4]

$>$ Breach of trust

$>$ Misrepresentation of advertisement

$>$ Theft of trade marks

$>$ Theft of patent

$>$ Tax evasion

$>$ Misappropriation of property

$>$ Breach of trade loss

$>$ Call for a product of another one to be himself.

\section{Root Causes Behind Commission of White Collar Crime}

In general, the causes of White Collar Crime are the economic difficulty and greed. There are other causes such as opportunity to commit crime, situational pressure on the individual and the issues pertaining to integrity. Many scholars on the other hand believe that the greed is not main reason for White Collar Crime, but the inherent characteristics of getting more than others are the main causes of white collar crime. However, there are various reasons for White Collar Crime, such as:

- Not really crimes: Some offenders convince themselves that their actions are not really crimes because the acts involved do not resemble street crimes. For example a pharmacist who chisels customers on prescription drugs may rationalize her behaviour by telling herself that it does not really hurt anyone.

- Not understandable/realizable: Some business people feel justified in committing White Collar Crimes because they believe that government regulations do not really understand the business world or their activities or the problems of competing in the free enterprise system.

- Unawareness of people: One of the prime causes of White Collar Crime is ignorance of people about this crime. As the nature of the crime is totally different from traditional crimes, people rarely understand it though they are the worst victims of such crime. The more awareness will increase among people the less will be the numbers of White Collar Crime.

- For Greediness: Rationalizing greed is a common trait of White Collar criminals. Some white collar criminals believe that everyone violates business laws, so it is not so bad if they do so themselves. So greed is another motivation for White Collar Crime.

- Necessity: Greed is not the only motivation for White Collar Crime, need also pays an important role. Executive may temper with company books because they feel the need to keep or improve their jobs, satisfy their egos or support their children. Women convicted in lowerechelon positions and their acts seem motivated more out of economic survival than greed and power.

- For Social and economical changes: The rise of White Collar criminality in many countries has coincided with the progress made in those countries in the economic and industrial fields. It is hardly surprising that the two processes should go together considering that most of the White Collar Crimes are, directly or indirectly, connected with the production and distribution of wealth.

- Scientific and technological development: The advance of technological and scientific development is contributing to the emergence of 'mass society', with a large rank and file and small controlling elite, encouraging the growth of monopolies, the rise of a managerial class and intricate institutional mechanism. The inability of all sections of society to appreciate in full this need results in the emergence and growth of White Collar and economic crimes.

Besides the above discussed causes, it is necessary to mention some other common factors which are responsible for the commission of White Collar Crimes: [5]

- Economic and industrial growth 
- Socio-economic change in the society

- Recent development of IT

- Opportunities created by corporate culture

- Family pressure

- Lack of effective punishment

- Passiveness of government

- The lengthy and defective procedures of the courts etc.

\section{Distinction between White Collar Crime (WCC) ANd Blue Collar Crime (BCC)}

There are various types of distinctions between the two which are as follows:

- WCC is a crime committed by person of upper socio-economic class in the course of occupation. On the other hand, BCC is a crime committed under various penal laws.

- The nature of WCC is money related criminal in nature. But, the nature of BCC is completely criminal in nature.

- The financial loss and gravity of consequence of WCC to society is far greater than general crime. As WCC affects whole society and BCC affects only the victim or victim's family.

- In case of WCC the court cannot enforce punishment. Since criminals escape themselves easily, this can never be found in case of BCC.

- The core purpose of WCC is to gratify greed. On the other hand, the basic purpose of BCC is necessity or any other reasons.

- The quality or position of White Collar criminals are such that they are so intelligent, stable, successful and men of high social status. But the general criminals are not like that of qualities previously mentioned. [6]

- In case of WCC there is possibility of violation of trust which is absent in case of BCC.

- Another notable feature of WCC is that there is no any existing legislation in our country to prevent WCC. But there are various types of penal statutes existing now in Bangladesh in different fields.

- White Collar criminals are intelligent, stable successful and men of high social status. They are foresighted persons belonging to the prestigious group of society. On the contrary, Blue Collar criminals are ordinary, common, and men of comparatively lower social status.

- White Collar Crimes, which are committed in commercial world, are indirect, anonymous, impersonal and difficult to detect. But ordinary criminal commit crimes, which are direct and involve physical action such as beating, removal of property or use of force etc. It can easily be identified and detected.

- Ordinary crimes are more common such as assault, robbery, dacoity, murder, rape; kidnapping and other acts involving violence etc. which are mostly committed by the underprivileged class. On the other hand, the privileged prestigious class and large corporations are involved in White Collar Crimes.

- The criminal content such as mensrea or guilty mind is an essential ingredient of every traditional or Blue Collar crime but many statutes dealing with White Collar Crime do not require mensrea in strict sense of the term, yet doctrine of constructive mensrea applies in such cases.

\section{SOME COMMON White COLlar CRIMES in BANGLADESH}

Here it is so much expedient to state some of the common White Collar Crime committed in Bangladesh, and these are as follows: 


\subsection{Fraud}

It means to engage in an act or pattern of activity where the purpose is to defraud a bank of funds. A false representation of a matter of fact, whether by words or by conduct, by false or misleading allegations, or by concealment of what should have been disclosed, that deceives and is intended to deceive another so that the individual will act upon it to her or his legal injury.

\subsection{Blackmail}

It is a demand for money under threat to do bodily harm, to injure property or to expose secrets.

\subsection{Bribery}

It is the most common crime committed in each and every government institution for when money, goods, services or any information is offered with intent to influence the actions, opinions and decisions of the taker, constitutes bribery.

\subsection{Cellular Phone Fraud}

It refers unauthorized use or tampering or manipulating cellular phone services.

\subsection{Embezzlement}

When a person who has been entrusted with the money or property but the money or property is not returned; and used for his or her own purpose.

\subsection{Counterfeiting}

Copies or imitates an item without having been authorized to do so is counterfeiting.

\subsection{Forgery}

When a person passes false or worthless instruments such as cheque or counterfeit security with intent to defraud.

\subsection{Tax-Evasion}

Frequently used by the middle-class to have extra-unaccounted money. Tax evasion is using illegal means to avoid paying taxes. Typically, tax evasion schemes involve an individual or corporation misrepresenting their income to the Internal Revenue Service. Misrepresentation may take the form either of underreporting income, inflating deductions, or hiding money and its interest altogether in offshore accounts. Proof of the crime requires first proving the attendant circumstance that an unpaid tax liability exists.

\subsection{Adulteration}

Adulteration of foods and drugs by affluent businessmen is one kind of white collar crime. And

\subsection{Professional Crime}

Crimes committed by medical practitioners, lawyers etc. in course of their occupation are professional white collar crime. They include medical profession, engineering, legal practice, private educational institutions etc.

\subsection{Credit Card Fraud}

Credit card fraud is a form of identity theft that involves an unauthorized taking of another's credit card information for the purpose of charging purchases to the account or removing funds from it. Credit card fraud schemes generally fall into one of two categories of fraud: application fraud and account takeover.

\subsection{Money Laundering}

It is illegal way to transaction money from one country to another one for illegal purposes. In other sense, Money laundering refers to a financial transaction scheme that aims to conceal the identity, source, and destination of illicitly-obtained money.

\subsection{Corporate Crime}

Corporate crime deals with the company as a whole. The crime benefits the investors or the individuals who are in high positions in the company or corporation. The relationship white collar 
crime has with corporate crime is that they are similar because they both are involved within the business world. Their differenced is that white-collar crime benefits the individual involved. And corporate crime benefits the company or the corporation.

\section{Impact of White Collar Crime and Essence of Special Enactment to Prevent White COLlar CRIMES}

White Collar Crimes are so harmful to society that they directly affect the financial condition of the country. A few effects of such crimes are as under-

\subsection{Dangerous to Society}

White Collar criminality is a curse to society because such crimes not only put the nation into a great financial loss but also causes fall in moral values. [7]

\subsection{Crime against Society}

It is actually an offense of 'treason'. The methods by which the taxes are evaded or black money is floated in the market etc. are such offences, which are committed purely for the personal gains at the cost of heavy loss to State. [8]

\subsection{Economic Misbalance}

When a group of persons belonging to rich and resourceful class, through their unlawful sources, gain more and more profit, the majority class suffers the evils of it. [9]

\subsection{Adverse Effect on Future Generation}

When the whole economy of a nation is disturbed by White Collar criminality, the future generation will suffer from poverty, unemployment. [10]

\subsection{Loss to Government Revenues}

When white-collar criminals evade taxes or pay fewer taxes, the whole fiscal policy to the Govt. is disturbed. [11]

\subsection{Impact on Society due to Hoarding}

While the country is affected by natural disaster like flood, cyclone, draught, and also by the economic slowdown or inflation, some of influential political person (especially from the opposition) try to store huge amount of daily necessary goods. As a result, there is an artificial crisis of goods in the market and the price of goods ultimately rises. So, due to that mal-practice, the society is affected in different ways considering a huge amount of financial loss. [12]

\subsection{Misrepresentation of Law}

There are some punishments which are enumerated in the Penal Code, 1860 about taking bribe or forgery. But, white-collar criminals embezzle a huge amount of money through mischief or corruption. But, they are not punished properly. Since they don't think that, they do not commit any offence at all.

\subsection{Impact on Judicial Sector}

Today, the criminal gangs have their advocates who are highly paid by the criminals and they lead criminals of our society to fly away from the ambit of punishment by inducing the judicial officers as well as the Law Enforcing Agencies.

\subsection{Impact on Infrastructural Progress}

In the construction work of the government, most of the time a big amount of money is being embezzled by the white-collar criminals. For this reason, the highway, multi-purpose bridge, and the government infrastructure are falling down before the schedule time of completion. And the infrastructural progress of the country is in turns, getting ruined.

\subsection{Impact on Parliamentary Budget}

Through the report of GFI (Global Financial Integrities) in the last decade, six lacks cores of money are smuggled to other countries. If this amount of money is refunded into the banks of our country, then the country will be benefited in several ways other than facing a huge amount of loss. 


\subsection{Impact on Medical Sector}

Most of the doctors refer passion for various types of medical tests in their pre-arranged diagnostic center and prescribe medicine of those companies who give them more and more sample of drugs simultaneously and other facilities. All these are the examples of white-collar crimes but they are not strongly punished due to lack of proper laws.

\subsection{Impact of White-Collar Crimes on Educational Sector}

Educational sectors are getting ruined day by day due to White Collar Crimes radically. A huge financial endowment from various foreign resources like HEG projects has been misappropriated by the policy-maker of the educational ministry of the government. As a result, research sectors of the universities are not benefited properly. And the educational system of our country is getting worse day by day.

Since these crimes are mostly committed by the dignitary and influential persons of the society so the government organizations is not seen to willingly take proper and immediate action against them. In most of cases, these kinds of crimes don't impair us directly but deadly affect our society. These crimes are committed by such kinds of persons who are socially, economically and occupationally well established as well as influential in the society. Usually common people cannot make out these types of crimes. Although they can perceive the outcome of these crimes on them but in this case they have nothing to do. As they are stranded so that they cannot go against the actions of White Collar criminals. In this regard, these criminals are reluctant to suppose their activities as crime. And for the purpose of controlling these White Collar Crimes in Bangladesh a special enactment is very much urgent to be passed by our sovereign law making authority.

\section{RECOMMENDATIONS}

In a country like Bangladesh where large scale starvation, mass illiteracy and ignorance affect the life of the people, White Collar Crimes are bound to multiply in large proportion. Control of these crimes is a crucial problem for the criminal justice administration in this country. However, some of the important and crucial recommendations for combating White Collar criminality are going to be stated as follows:-

- Creating public awareness against these crimes through the media of press, platform and the other audio-visual aids. Intensive legal literacy programmes may perhaps help in reducing the incidence of White Collar criminality to be a considerable extent.

- Special tribunals should be constituted with power to award sentence to imprisonment up to the highest punishment under the Special Act.

- Stringent regulatory laws and drastic punishment for White Collar criminals may help in reducing these crimes. Even legislations with retrospective operation may be justified for this purpose.

- A separate chapter on White Collar Crimes and socio-economic crimes should be incorporated in the Special Act by amending the Code so that White Collar criminals who are convicted by the court do no escape punishment because of their high social status.

- White Collar offenders should be dealt sternly by prescribing stiffer punishments keeping in view, the gravity of injury caused to the society because of these crimes. The Supreme Court, in M. H. Haskot v. State of Maharashtra, in this context observed, "Soft sentencing justice is gross injustice where many innocents are the potential victims".

- There is an urgent need for a National Crime Commission which may squarely tackle the problem of crime and criminality in all its facets.

- Above all, public vigilance seems to be cornerstone of anti-white collar crime strategy. Unless the white collar crimes become abhorrent to public mind, it will not be possible to contain the growing menace. In order to attain this objective, there is need for strengthening of morals particularly, in the higher strata and among the public services. It is further necessary to evolve sound group-norms and service ethics based on the twin concepts of absolute honesty and integrity for the sake of national welfare. This is a possible through character building at 
grass-root level and uncalculating a sense of real concern for the nation among youngsters so that they are prepared and trained for an upright living when they enter the public life.

- Necessary amendments should be made in existing laws.

- Moreover, a separate and distinct enactment should be passed by our national parliament.

- The rules and regulations of the said enactment (if any) should be flowed and implemented by the court and Law Enforcing Agencies.

- Moreover, a separate and compulsory chapter relating to White Collar criminality should be introduced in the course curriculum of all the departments in university level.

\section{CONCLUSION}

White Collar Crime includes a variety of law violations by individuals or groups that hold significant positions in society, violations that can have a serious impact on society. These criminals are publicly very much respectful to the law of the country. But in practical their attitude is looking like a dacoit in their professional interest. Lack of proper punishment, they commit crimes again and again. At the very end of the study, it is found that White Collar Crime is a heinous monetary crime. Its effects and impacts on the society is very much severe than Blue Collar Crime. Even the White Collar Criminals very often escape from punishment themselves exercising their power and money. So, it has become a crying need to enact special laws by the government to get rid of from this severe crime for the greater interest of the nation.

\section{REFERENCES}

[1] E. H. Sutherland, 'Is White Collar Crime' Crime?” American Sociological Review, 10: 132-139 (April, 1945).

[2] E. H. Sutherland, White Collar Crime, Dryden Press, New York, 1949, pp. 112-116.

[3] Uddin,Borhan, Criminology, Shams Publications, Dhaka, 2015, p-146.

[4] E. H. Sutherland, White Collar Crime, Dryden Press, New York, 1949, p.132.

[5] Hossain, Shaikh, Rajib, Lectures on Criminology \& Penology, Roots 99 Publications, Dhaka, 2015, p. 133.

[6] N.V. Paranjape, Criminology and Penology, Central Law Publications, Allahabad, 2012, pp. 127-129.

[7] Hossain, Shaikh, Rajib, Lectures on Criminology \& Penology, Roots 99 Publications, Dhaka, 2015, pp .139 .

[8] Ibid, p.140.

[9] Ibid.

[10] Ibid.

[11] Ibid.

[12] Roy, Panna, Rani, Criminology, Oporajita Prokashan, Dhaka, 2015, pp. 205-206.

\section{AUTHORS' BIOGRAPHY}

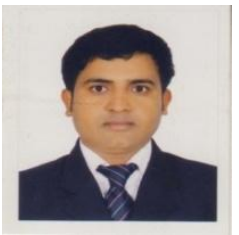

Aroj Ali is a Lecturer and Head at Department of Law of North Western University, Khulna, Bangladesh. He completed his LL.B. (Hons) and LL.M. degree from the University of Rajshahi, Rajshahi, Bangladesh. He is also an advocate (nonpracticing) and a member of Magura Bar Association, Bangladesh. He has research interest on contemporary legal issues.

Citation: Aroj Ali. "Impact of White Collar Crime and Essence of Special Enactment: Bangladesh Perspective" International Journal of Humanities Social Sciences and Education (IJHSSE), vol 6, no. 2, 2019, pp. 41-49. doi: http://dx.doi.org/10.204 31/2349-0381.0602006.

Copyright: () 2019 Authors. This is an open-access article distributed under the terms of the Creative Commons Attribution License, which permits unrestricted use, distribution, and reproduction in any medium, provided the original author and source are credited. 